than conform strictly to the method followed in the different portions of the latter; that is, to give a history of facts observed, arrange them in order, and draw from their comparison the true character of the object treated of. "We ought never," he says, " to hope to guess at or to domineer over Nature; we can but listen in silence to, and meditate attentively over, the phenomena we observe; we can but discuss them carefully, and gather from them such truths as shall be useful." My aim has been to work after this fashion.

In conclusion, sir, if I have not in very word complied with the conditions of the bequest of Dr. Theodore Goulston, "that a dead body was, if possible, to be procured, and two or more diseases treated of", I have at least brought the pictured results of the post mortem room within the College, and treated, however imperfectly, of an affection which is Protean in its anatomy, if not in its features. Following out, at any rate, the feeling which, as Censor of this College between the years I6I5 and 1626, he had probably attempted to inculcate, that not without the scalpel would the bounds of knowledge be widened, I may say, in the words which his perhaps greater successor in this Fellowship makes use of, "Non solum manus pro virili medicas languidis corporibus adhibendi, verùm etiam defunctorum cadavera introspiciendi quàm sæpissimè ansam arripui" (Morton, ops. cit., Ad Lect.). Yet it may be that whatever I have said on the subject I have had the honour to bring be fore you only illustrates once more the twice-told sentence of Bacon (Noz'um Organon, liber i, xlv; and Advancement of Learning, book ii) "The spirit of man feigns in Nature a simplicity and uniformity greater than really is". It may be that the conclusions to which I have been almost irresistibly led as to what seems to me to be the simple nature of pulmonary consumption may fail to be real, when scanned by some more searching eye than my own; and, if it be so, for work at least honestly attempted some consolation may be found in the words in which Heberden speaks of the uncertainty of modes of treatment "No aphorism of Hippocrates holds truer to this day than that in which he laments the length of time necessary to establish medical truths, and the danger, unless the utmost caution be used, of our being misled, even by experience." (Comm., ISo2, p. 7 I.)

\section{ON THE OPEN AIR TREATMENT OF CONSUMPTION.}

By JAMES BLAKE, M.D., F.R.C.S., San Francisco, California.

AN article in the JOURNAL for October 24 th, 1874 , recalls an intention I have had for some time of sending a communication on the open air treatment of consumption, a plan I have advocated for many years, both on the grounds to which Dr. Marcet alludes as to its being a septicæmia, and also on account of the advantages which such a treatment offers for improving the digestive organs. In a paper published in the San Francisco Medical and Surgical foumal, in 1860 , I pointed out the advantages to be derived to the digestive functions by living in the open air; but looking at the septicæmic element of the disease, no other treatment, it appears to me, can so effectually combat it as living in the open air, the only condition in which a patient with diseased lungs can avoid rebreathing the poisoned air he has expired, laden with the germs for intensifying the putrefactive processes going on to his lungs. There is undoubtedly a germ of truth in the theory of Dr. Mac Cormac of Belfast, that the chief cause of consumption is rebreathed air, but not, I think from its being overcharged with carbon, as he supposes, but because it is loaded with a much more subtle poison in the putrefactive germs which it contains. Some twelve years ago, I published some cases in the American fournal of Medical Sciences, showing how many cases of consumption had been arrested, and some cured, by what I called the open air treatment of the disease ; and a longer experience has convinced me that this method offers the best chance for our consumptive patients. But, before the profession can be induced to employ it, I am aware that an accumulated mass of prejudice has to be removed, not only amongst physicians, but more particularly amongst the public, as regards the evil of exposure and living in the open air. The idea of advising a patient in the third stage of consumption, suffering from cough and night-sweats, to sleep in the open air, is a proposition which in England, I am aware, would be considered not only as dangerous, but almost as a sign of lunacy. Even here, where it is no very uncommon thing for persons to sleep out of doors, and where the dewless nights of our mountain ranges during our rainless summers render any covering but blankets and a tree quite superfluous, I often met with objections to following such a course. And yet I am convinced that it is the best method that we possess for arresting and curing consumption. In England possibly, and in fact in most parts of Europe, the occasional summer rains and the absence of dry mountain ranges, with their pine-covered ridges, offer obstacles to such a treatment being fully carried out; but the principle once recognised, a great deal may be done even there towards employing it. In order, if possible, to remove to a certain extent this prejudice, I would state that I have never in a single instance seen any ill effects result from it. I have sent out patients to sleep in the open air who were so far reduced that they could not even ride on horseback, but had to be conveyed in a carriage. The difficulties and annoyances of living in the open air are, I believe, entirely in the ima. gination. The most arreeable holidays I have ever spent have been whilst camping out with a sensible party of ladies as well as gentlemen, and never have we broken up camp to return to houses without regret by all the members of the party. When ladies are in the party, it is better to have a tent, the front of which must always be fully open at night. During the winter months, the southern part of the State about San Diego or Santa Barbara is the most desirable place for patients, as there are seldom more than a dozen rainy days during the year; but in the summer the coast range of mountains north of San Francisco offers by far the most congenial climate, far better than that of the Sierras, owing to the greater equability of the temperature. From the middle of May to the end of October, as a general thing, living in the open air can be enjoyed without any fear of rain. As the summer heat increases, the higher mountains, up to 4,000 or 5,000 feet, ensure an agreeable climate, where the thermometer never rises ahove $85 \mathrm{deg}$. (this, in the dry air of the mountains, is about the same, as far us our sensations are concerned, as 70 deg. in England), and never descends below 55 deg., ranging generally from $60 \mathrm{deg}$. to $75 \mathrm{deg}$. during the twenty-four hours. As a general thing, at heirrt above I, 500 feet, the camp can be made in pine-woods, and $I$ believe that there is something antiseptic in the exhalations of these trees; certain it is that they impart a most agreeable odour to the air, particularly in warm weather. As for the cost, the expense is slight, as there are no hotel bills to pay; the journey across the continent is now rendered so easy that an invalid can generally support it without inconvenience, and in fact improve during the trip. In the cold weather, the trip can be made by the steamer to Colon, and thence to San Diego by the Pacific Mail Company's ships.

\section{THERAPEUTIC MEMORANDA.}

\section{CASE OF RHEUMATIC FEVER TREATED BY SALICINE.}

Miss O. R., a strong healthy girl, aged 15 , came under my care on May 3rd, suffering from rheumatic fever. She had been ill for four days, but had not been seen by any medical man. On May 3 rd, she had high fever; pulse 120; temperature 105 deg. The tongue was moist and furred. The knees and ankles were painful and swollen ; the right foot and ankle cold and livid. I prescribed bicarbonate of potass in ten-grain doses every third hour, and a linseed-meal poultice to the right knee and foot; the nourishment to consist of beef-tea and milk. On May 5th, the boweis had been moved four times during the night. She did not sleep, and was very thirsty. The pain had moved to the wrist and knuckles. M Iorning temperature ro5 der.; pulse 126 ; evening temperature $105.6 \mathrm{deg}$. I discontinued the bicarbonate of potass, and ordered chalk mixture and catechu, and the joints to be enveloped in cotton-wool. On May 6th, she was very delirious during the night. The bowels had been moved six times. The urine was scanty ; I did not see any of it. Owing to her helplessness and pain, she would not use the bed-pan. Temperature, morning 105 deg.; evening I05.3 deg.; pulse I2O, very weak. This day I had the advantage of a consultation with my friend Dr. McClelland of NewtownMount-Kennedy. The pain was principally in the back and hips. The heart-sounds were normal-May 7 th She had a very restless night. The bowels were moved several times. She had perspired freely since the commencement of her illness. The tongue was furred and moist; the knees were swollen and very painful. She could not bear the weight of the bedclothes. Pulse I2O; temperature, morning I05.2 deg.; evening 105.2 deg.

From the favourable mention made of salicylic acid and salicine in the treatment of rheumatic fever in the lBRitish MEdical Journal of May 6th, I determined to give salicine a trial (not being able to procure the acid at the time), and ordered twelve grains every third hour, discontinuing all other medicine. On May 8th, she had a better night. The pain had moved to the shoulders and back of the neck. The bowels were moved only once. Pulse IIO, and strong; temperature, morning, $103 \mathrm{deg}$. (a fall of 2.2 derr.). She said she felt better, and thought the powders had done her good. Temperature, evening, 